\title{
Homebuying: a Critical Perspective on Financial Costs and Gains
}

\author{
Adriana Mihaela Soaita (corresponding author) \\ University of St Andrews, Centre for Housing Research \\ The Observatory, St Andrews, KY16 9AY, UK \\ adriana.soaita@st-andrews.ac.uk \\ Beverley Searle \\ University of Dundee, School of the Environment \\ Perth Rd, Dundee, DD1 4HN \\ b.a.searle@dundee.ac.uk
}

\begin{abstract}
In Britain, the shift from the ideology of homeownership into one of homeownership-based welfare has been sustained by homebuyers being regarded as investors. Homeowners are expected to create a synergy between the owned house seen as a space of shelter, place of home and increasingly, an investment vehicle and an object of debt. Drawing on 80 interviews with owner-occupiers and national data on house prices and mortgages, we examine the way in which the meanings of home meanings are negotiated through the subjective calculation of the financial costs and gains of homebuying. We explore homebuyers' debt amnesia, their miscalculation of gains and their disregard of inflation. However homebuyers' financially unsophisticated understanding of the asset-home arises less from book-keeping complexities or difficulties in pricing the emotional domain of the home, but rather by them instinctively considering the alternative cost of a rented space of shelter. From this financial perspective and given affordability, homebuying illustrates a misleading ideological notion of choice.
\end{abstract}

Keywords: home-ownership; housing finance; housing economics. 


\section{Critical Housing Analysis}

\section{Introduction}

Neoliberal policies and implications of ageing societies have given rise to households' strategies and government policies which have increasingly framed the owned home as an asset-base for family welfare. This shift from the ideology of homeownership to one of homeownership-based welfare (HBW) - and more broadly from the socialisation to the individualisation of risk and welfare - has been questioned in reference to the consequences of the unequal distribution of housing wealth across regional and local markets, between boom-and-bust cycles, and across socioeconomic groups and age cohorts. Additional questions arise regarding homebuyers' abilities to create positive synergy across the multiple meanings of the owned house as a space of shelter, a place of home, a store of wealth and an object of debt. Drawing on 80 interviews with owner-occupiers and national data on house prices and mortgages, we explore the intertwining of the home's multiple meanings in the subjective calculation of the costs and gains of homebuying. Section 1 succinctly reviews the changing nature of the asset-home. After a description of methodology (section 2), section 3 calculates the costs and gains of homebuying using national averages for home values and mortgage rates and explores the socially-constructed nature of homebuyers' debt amnesia. Section 5 adjusts these figures for inflation. Section 6 concludes the article by showing that homebuyers' unsophisticated understanding of the financialisation of their asset-home - that is their debt amnesia, illusory miscalculation of gains and disregard of inflation - is less a reflection of the complexities of book-keeping and difficulties in pricing the emotional domain of home, but is more about their instinctive consideration of the alternative costs of a rented space of shelter. From this financial perspective and given household affordability, homebuying illustrates a misleading notion of choice.

\section{The changing nature of the asset-home}

A dwelling - we will use the Scottish term 'house' which applies equally to houses and flats has been recognised as holding different meanings, those of a space of shelter, a place of home, a store of wealth, a symbol of consumption and increasingly an investment vehicle and an object of debt (Smith and Searle 2010). An examination of the ideological allegiances and policies that have privileged some meanings over others across time is beyond the scope of this article. We will focus instead on the repositioning of the owned house as an investment vehicle and an object of debt within the ideological shift from homeownership to HBW (Ronald and Elsinga 2012).

Broad policy trade-offs have been recognised between predominantly renting versus homeowning societies. For instance Kemeny (1981) argued that housing costs were comparable across household lifecycles between homebuying and non-profit renting. However, the UK housing system has since been systemically transformed. More households are now forced to rely on the private rental sector for longer where market rents now outstrip monthly mortgage payments (CML 2011). Financing a mortgage has also been observed as a policy trade-off between homeownership and pension provision. While the observation holds in terms of cross-country comparative welfare systems (Ronald and Elsinga 2012), household wealth distribution by deciles in the UK shows that those having greater housing wealth also have greater private/occupational pension wealth. Kemeny (1981) argued that the expansion of homeownership inescapably results in the individualisation of welfare given that debtoverburdened households demand/accept tax reductions and welfare cuts. Housing wealth has 
now become a key base for family welfare. The asset-home has been converted into a source for releasing considerable sums required to cover welfare needs (Smith and Searle 2010). Conversely, people who lack assets are condemned to pay high rents and may face long term poverty.

The risks of homeownership have long been recognised. The deregulation of finance has increased access to homebuying to many marginal households. The devastating effects of the US sub-prime financial crisis have been well documented and clearly showed the socioeconomic costs of enticing low-income households into homebuying. The case of lowermiddle income households buying homes they could hardly afford was also seen as a 'a pitiful form of social suffering' (Bourdieu 2005); homeownership failed to offer the residential freedoms of the affluent while adding financial pressure to stretched households' budgets and increased risks arising from uninsurable life-course events (e.g. unemployment, illness or divorce). While HBW strategies rely on ever increasing growth in home values, the accrued capital gains are volatile and unequal. The unequal distribution of housing wealth across regional and local markets, between boom-and-bust cycles, and across socioeconomic groups and age cohorts has been well documented. Depending on when and where one enters homeownership, the likelihood of facing severe negative equity for a long time - leading to repossession or residential traps - or conversely of benefiting from capital gains varies significantly. While the effect of geography and time are independent, they are nonetheless patterned by social class and cohorts.

Table 1: Sample distribution

\begin{tabular}{|c|c|c|c|c|}
\hline Birth cohort & $\begin{array}{c}\text { Outright } \\
\text { with cash }\end{array}$ & $\begin{array}{c}\text { Outright by } \\
\text { mortgage }\end{array}$ & Mortgagors & Re-mortgagors \\
\hline $35-49$ & 5 & 0 & 11 & 9 \\
\hline $50-65$ & 12 & 21 & 11 & 11 \\
\hline
\end{tabular}

The shift to the broader individualisation of welfare, within which HBW is seeded, has relied on the construction of the worker-homebuyer as a responsible, self-interested, financiallyknowledgeable investor subject (Langley and Leaver 2012). Adopting insights from behavioural economics, policy-makers have recognised key challenges in reshaping citizens into entrepreneurial investors. For instance, in figures unadjusted for inflation, average house prices across the UK have never (or only slightly) fallen since 1980, which has mythified the extent of capital gains accrued via homeownership whereas accounting for the real costs of homebuying remains a difficult exercise for most individuals. Finally, emotions, meanings and expectations from the house as a place of home and symbolic capital certainly intersect with the economics of homebuying (Smith and Searle 2010).

\section{Methodology}

During June-December 2013 we conducted 80 semi-structured telephone interviews with homeowners. The sample was nested in the 2012 Family Resources Survey in order to achieve national coverage (response rate 34\%). Interviews lasted on average one hour; they were recorded, transcribed and coded using NVivo software. Our target age group comprised two relatively distinct cohorts (Table 1) being engaged in different stages of their housing careers. Household annual income was spread from very marginal to very affluent levels in both groups: 35 respondents earned below $£ 30,000$; 31 respondents earned between $£ 30,001$ 
and $£ 60,000$; and the remaining participants earned more than $£ 60,001$. Similarly, selfdeclared home values ranged from $£ 40,000$ to $£ 800,000$ and accrued equity from $£ 6,000$ to $£ 500,000$.

\section{Gross costs and gains}

Table 2 shows the gross costs and gains of homebuying over four 25 year periods, and subsequent house value growth to 2015 . We used average UK-wide house values (Nationwide Price Index). Mortgage costs were tracked over the 25 year term of a standard variable rate mortgage (Building Societies Association). No account has been taken of additional purchase costs (e.g. stamp duty) or costs of maintenance, improvements and homemaking (e.g. furnishing). We have assumed that each purchase is financed through a $20 \%$ deposit $/ 80 \%$ mortgage. The columns headed 'profit' are calculated as follows:

- 'Profit 1' represents the house value at end of mortgage term less value at date of purchase. This represents the gross growth in house value over the mortgage term and does not take into account that the purchase was paid for with a deposit and a mortgage, and not with cash.

- 'Profit 2' represents the house value at end of mortgage term less the total purchase cost (including the costs of financing the mortgage). A homebuyer can only calculate Profit 2 at the end of the mortgage by summing the annual mortgage payments.

The difference between Profit 1 (cash purchased) and Profit 2 (mortgage financed) is impressive. Even though mortgagors paid two to three times the purchasing price over the mortgage term, borrowing costs have consumed between $27-38 \%$ of the illusory Profit 1 . Yet homebuyers still made on average significant financial gains, which were sustained by growth in house values of between 3.7 and 7.2 times over the mortgage term. If the growth in house values had only been half over each term, borrowing costs would have wiped out most of Profit 2. How did participants account for the costs and gains of homebuying?

Table 2: Gross costs and gains

\begin{tabular}{|c|c|c|c|c|c|c|c|c|}
\hline \multirow[b]{2}{*}{$\begin{array}{l}\text { Mortgage } \\
\text { period }\end{array}$} & \multirow{2}{*}{$\begin{array}{c}\text { Home } \\
\text { value at } \\
\text { date of } \\
\text { purchase } \\
\text { (a) }\end{array}$} & \multicolumn{3}{|c|}{ Costs of purchase: } & \multirow{2}{*}{$\begin{array}{c}\text { Home } \\
\text { value at } \\
\text { end of } \\
\text { mortgage } \\
\text { (e) }\end{array}$} & \multirow{2}{*}{$\begin{array}{c}\text { Profit } \\
1 \\
\text { Gross } \\
\text { capital } \\
\text { gains } \\
\text { (e - a) }\end{array}$} & \multirow{2}{*}{$\begin{array}{c}\text { Profit 2: } \\
\text { Gross } \\
\text { cost } \\
\text { deducted } \\
\text { gains } \\
(\mathrm{e}-\mathrm{b}-\mathrm{d}) \\
\end{array}$} & \multirow{2}{*}{$\begin{array}{l}\text { Subsequent } \\
\text { home value } \\
\text { growth to } \\
2015 \\
\text { (f) }\end{array}$} \\
\hline & & $\begin{array}{c}\text { Deposit } \\
\text { (b) }\end{array}$ & $\begin{array}{c}\text { Amount } \\
\text { mortgaged } \\
\text { (c) }\end{array}$ & $\begin{array}{l}\text { Mortgage } \\
\text { payments } \\
\text { (d) }\end{array}$ & & & & \\
\hline 1975-2000 & 11,288 & 2,258 & 9,030 & 27,802 & 81,628 & 70,340 & 51,568 & 120,982 \\
\hline 1980-2005 & 23,497 & 4,699 & 18,798 & 55,305 & 157,387 & 133,890 & 97,383 & 45,223 \\
\hline 1985-2010 & 35,436 & 7,087 & 28,349 & 73,477 & 162,971 & 127,535 & 82,407 & 39,649 \\
\hline 1990-2015 & 54,919 & 10,984 & 43,935 & 100,613 & 202,610 & 147,691 & 91,013 & - \\
\hline
\end{tabular}

Source: authors' analysis

\section{The financialised homebuyer and the asset-home}

Our participants entered the housing market as first-time-buyers between 1970 and 2012; 23 participants entered the mortgage market after 1990. Housing pathways were obviously much more complex than we assumed in our exercise. On average, the younger group were already living in their second-bought home and the older group in their third; only 20 participants had not changed residence since they first bought. Yet all participants enjoyed calculating the 
profit of homebuying in terms of Profit 1 - or even as the value difference between their current and first home - and they seemed unconcerned by costs of purchase(s):

I bought my first house for $£ 7,500$ and I sold the big house for $£ 315,000$ ! So, you don't make that sort of money by working for a living, if you know what I mean! (male 58).

Table 2 shows buying with cash is significantly cheaper than buying with a mortgage. Seventeen participants bought their current homes with cash. Ten participants were affluent homeowners living in large, expensive homes. Conversely, three participants deliberately bought inexpensive homes (non-standard; Council house) using their entire savings in order to reduce outgoings. ${ }^{1}$ Achieving outright homeownership was a symbolic stage, yet the real costs of sustaining the mortgage were totally overlooked by almost all participants and misunderstood even by those few who did try to pay the mortgage faster:

[Why don't people include the cost of borrowing?] That's a very good question. I don't know! As soon as you said it, I can see what you mean, that I have invested additional monies to finance the loan, so I really have got to subtract that from the differential from what I bought it. I guess I consider as sunk money really, you know? I never really gave it much thought that I should subtract that money off what I considered as a profit (male 41).

This comes at odds with findings reported in France (Bourdieu 2005) or views from our six non-British private tenants:

If I want to buy a house I have to have the money in my hand. I don't want to owe any money to anyone or to pay double for it (Hungarian female 38).

After later reflection, $\mathrm{Mr} \mathrm{KH}$ (35) texted to explain this debt amnesia in cultural terms:

We are very comfortable with debt. In fact, we are too comfortable! And some people have so much debt they cannot calculate (or would rather not know) the true cost. Debt is a way of life here, the true cost of goods does not matter to people.

Homebuyers' amnesia of debt was also sustained by a socially-accepted opacity in mortgage selling and the construction of mortgage annual statements, as recognised by interviewed financial experts.

...banks and mortgage lenders are not the most popular institutions. Why on earth would a lender say, 'Your mortgage has gone down from $£ 100,000$ to $£ 94,500$ this year, but by the way the cumulative payments you have made to us over the last ten years are $£ 680,000$ ?'

The chances of somebody keeping their annual financial statements and thinking 'Hang on; I have been charged $£ 240,000$ of interest payments on top of the $£ 100,000$ mortgage that I have paid back!' People don't do that, I can’t

\footnotetext{
${ }^{1}$ The remaining four participants downsized to bungalows.
} 
think of anybody who has got 25 years' of mortgage statements in their folder at home!

However, if the owned house was seen exclusively as an asset, a truly financialsed homebuyer would try to profit by paying the mortgage faster. A few of our participants did; conversely 37 participants (have) released funds by re-mortgaging. But the asset-home is also a space of shelter. By considering the imputed rents over the period, the gains of homebuying may well approximate to Profit 1. Overlooking mortgage payments seems then just a way of simplifying the complex terms of buying the asset-shelter-home. Participants emphasised:

After all it's a question of paying the bank or paying a landlord! So you're as well buying as long as you don't have to move around too much for your job (male 65).

Paying a mortgage was seen as being cheaper than renting. The rent was cast as 'dead/wasted money', 'paying someone else's mortgage' or a 'life-time liability' and homebuying as 'rentfree living' and creating an 'asset at the end of it' (recurring quotes). Participants' motives to engage in homebuying were deemed to be primarily financial yet a careful reading showed the way in which they reflected expectations, constraints and opportunities stemming from a housing system perceived as offering two tenure options, namely privately owning or privately renting. Given the huge potential gains, we challenge the notion of homeownership as a choice, when the alternative (renting) is financially positioned as a continuous liability. However, it is interesting to consider the effect of inflation on the costs and gains of homebuying.

\section{Looking through the lens of time}

Inflation affects both the value of money and house values. On the one hand, the purchasing power of money is diminished (10 years ago $£ 100$ bought more than today just as $£ 100$ today would buy more than it will in 10 years' time). On the other hand, house value growth contains two separate components. One is derived from general price inflation, which we refer as the RPIX factor. The other component can be regarded as an additional housing market affect, which represents the real growth in house values. Consequently, to calculate the inflation-adjusted profit of homebuying, one should deduct the adjusted total costs of purchase from the real growth in house values. The results are shown as Profit 3 in Table 3. We observe that real growth in house values has surpassed general price inflation resulting in real capital gains (column 'i'). However, when the adjusted costs of the mortgage are deducted, the real gains (Profit 3) are only notable for the period 1980-2010 while turning to very low or negative values for the first and last periods considered in our exercise. This reflects the UK boom-and-bust cycles and the corresponding risks of homebuying - even though subsequent gains (column ' $k$ ') yield positive gains. If gross cost-deducted gains (Profit 2 , Table 2) represented $62-73 \%$ of the illusory Profit 1 , adjustments for inflation mean that real gains represent between -3 and $32 \%$. However, if imputed rents are considered (which may approximate to the figures in column ' $\mathrm{g}$ '), the real profit of homeownership yields an impressive amount of unearned wealth. What are participants' views regarding the generative mechanisms of this unearned wealth? 


\section{Critical Housing Analysis}

Volume 2 | Issue 1 | 2015 | 65-73

Available online at www.housing-critical.com

http://dx.doi.org/10.13060/23362839.2015.2.1.177

Table 3: Inflation-adjusted costs and gains (national average)

\begin{tabular}{|c|c|c|c|c|c|c|c|c|c|}
\hline \multirow[b]{2}{*}{$\begin{array}{l}\text { Mortgage } \\
\text { period }\end{array}$} & \multirow{2}{*}{$\begin{array}{l}\text { Home } \\
\text { value at } \\
\text { date of } \\
\text { purchase } \\
\text { (a) }\end{array}$} & \multirow{2}{*}{$\begin{array}{c}\text { Costs } \\
\text { over 25 } \\
\text { years, } \\
\text { gross } \\
(\text { b }+ \text { d) }\end{array}$} & \multirow{2}{*}{$\begin{array}{c}\text { Costs } \\
\text { over 25 } \\
\text { years, } \\
\text { deflated } \\
\text { (g) }\end{array}$} & \multirow{2}{*}{$\begin{array}{c}\text { House } \\
\text { value at } \\
\text { end of } \\
\text { mortgage } \\
\text { (e) }\end{array}$} & \multicolumn{2}{|c|}{ Profit 1 (e - a), by: } & \multirow[b]{2}{*}{$\begin{array}{c}\text { Profit } 3 \\
\text { Inflation } \\
\text { adjusted } \\
(\mathbf{i}-\mathrm{g})\end{array}$} & \multirow[b]{2}{*}{$\begin{array}{l}\text { Profit } 3 \\
\text { as \% } \\
\text { from } \\
\text { Profit } 1\end{array}$} & \multirow{2}{*}{$\begin{array}{c}\text { Subsequent } \\
\text { housing } \\
\text { factor to } \\
2015 \\
\text { (k) }\end{array}$} \\
\hline & & & & & $\begin{array}{l}\text { RPIX } \\
\text { Factor } \\
\text { (h) }\end{array}$ & $\begin{array}{l}\text { Housing } \\
\text { factor } \\
\text { (i) }\end{array}$ & & & \\
\hline $1975-2000$ & 11,288 & 30,060 & 17,760 & 81,628 & 54,802 & 15,538 & $-2,222$ & -3 & 84,279 \\
\hline 1980-2005 & 23,497 & 60,004 & 38,976 & 157,387 & 51,463 & 82,427 & 43,451 & 32 & 16,020 \\
\hline $1985-2010$ & 35,436 & 80,564 & 54,825 & 162,971 & 48,076 & 79,459 & 24,634 & 19 & 22,741 \\
\hline $1990-2015$ & 54,919 & 111,597 & 76,700 & 202,610 & 69,381 & 78,310 & 1,610 & 1 & 8 \\
\hline
\end{tabular}

Source: authors' analysis

\section{'They always go up'}

Altogether, 73 out of 80 participants believed their home value increased significantly. Asked why house values increased (or decreased), participants proved to be free-market thinkers. Explanations in relation to macroeconomic fundamentals were clearly dominant and included notions of inflation (referred to by 30 participants), a self-explanatory 'housing market' (by 20 participants), lucky navigation of boom-and-bust cycles and demand-and-supply disequilibrium (by 13 and 11 participants, respectively). ${ }^{2}$ Other major explanatory factors were the undertaking of financially smart improvements (by 24 participants) and the choice of good locations (by 20 participants) by which participants were able to negotiate a balance between the owned house as a place of home and as a financial asset:

It has been done up considerably from what it was, so that has increased the value. But I did it to make it into my home, not because I was considering future value (female 46).

However given space constraints and the particular relevance to our topic, we focus on homeowners' views regarding inflation. The self-explanatory and reified housing market was deemed to always inflate property values even though participants were well aware of boomand-bust cycles. Risks of loss were overlooked by strong beliefs in long-term growth in house values. The relation between property and general price inflation was most ambiguous. The idea of general inflation was perceived within the frame of historic determinism by some participants in terms of 'the way of the world', 'the historic feel' or it elicited a childlike amazement as below:

We were talking in the office about the Mars bar. When I was a child that used to be the equivalent of $2 p$, it's now $80 p$ ! So the cost of living has done that! [By 40 times!] No, by 400 times! (male 62).

These figures were indeed correct according to the inflation index but this participant's astonishment is perhaps more telling regarding the extent to which individuals tend to exaggerate the effects of inflation on living costs. Conversely inflation was disregarded in the calculation of housing gains, except by five participants who believed house values stay flat relative to general inflation. While participants showed off their accrued capital gains in gross figures, these were also downplayed as just 'paper money'. The meanings of the owned house

\footnotetext{
${ }^{2}$ Named by fewer than five participants: people confidence, the state of the economy and easy credit.
} 
as a space of shelter, a place of home and a store of wealth remained inescapably intertwined and simultaneously embedded into the past, present and future dimensions of time:

It was irrelevant to whether we bought and whether values went up or down because at the end of the day you can't eat a house; everyone needs somewhere to live... if I sold the property now and put the money in the bank that would be silly... and where would I live? It's something usually you leave to your children unless disaster comes in the form of old people's home (male $65)$.

\section{Conclusions}

In this paper we have evidenced homebuyers' debt amnesia, their illusory miscalculation of gains and their ambiguous views about inflation. However we have shown that homebuyers' financially unsophisticated understanding of the asset-home arises less from book-keeping complexities or difficulties in pricing the emotional domain of the home, but rather from discounting the alternative cost of a rented space of shelter. Overall homebuying generates an impressive amount of unearned wealth even after deducting the full cost of financing a mortgage and adjusting for inflation. This has important consequences for whether and how housing gains should be taxed. From this financial perspective and given household affordability, homebuying illustrates an ideologically misleading notion of choice.

\section{Acknowledgements}

We thank Mr Stewart Cowe BSc, FFA (former Investment Director Property Research and Strategy Scottish Widows Investment Partnership) for conducting the calculations reported in Tables 2 and 3. The article was prepared under the project Mind the (Housing) Wealth Gap, funded by the Leverhulme Trust. 


\section{References}

Bourdieu, P. 2005. The Social Structures of the Economy. Cambridge: Policy Press.

CML. 2011. 'First-time Buyers and Affordability: A Fresh Perspective.' News \& Views, 26. Retrieved March 5, 2013, from http://www.cml.org.uk/news/390/.

Kemeny, J. 1981. The Myth of Home Ownership: Private versus Public Choices in Housing Tenure. London: Routledge.

Langley, P., A. Leaver 2012. 'Remaking Retirement Investors.' Journal of Cultural Economy, 5, 473-488. DOI: 10.1080/17530350.2012.691893.

Ronald, R., M. Elsinga 2012. Beyond Home Ownership: Housing, Welfare and Society. Abington: Routledge.

Smith, S. J., B. A. Searle 2010. The Blackwell Companion to the Economics of Housing: The Housing Wealth of Nations. Singapore: Wiley-Blackwell. 